\title{
QUICK ADAPTATION OF RALSTONIA SOLANACEARUM TO COPPER STRESS TO RECOVER CULTURABILITY AND GROWTH IN WATER AND SOIL
}

\author{
Sergio Daniel Moreira Ascarrunz ${ }^{1 *}$, Tomohide Natsuaki ${ }^{2}$, Hitoshi Honjo ${ }^{2}$, Ryo Fukui ${ }^{2}$ \\ ${ }^{1}$ United Graduate School of Agricultural Science, Tokyo University of Agriculture and Technology, 3-5-8 Saiwai-cho, Fuchu, \\ Tokyo 183-8509, Japan; ${ }^{2}$ Department of Bioproductive Science, Faculty of Agriculture, Utsunomiya University, 350 Mine, \\ Utsunomiya, Tochigi 321-8505, Japan.
}

Submitted: August 03, 2010; Returned to authors for corrections: October 14, 2010; Approved: January 13, 2011.

\begin{abstract}
Cells of Ralstonia solanacearum were exposed to $\mathrm{Cu}$ in distilled water, and the resulting $\mathrm{Cu}$-stressed nonculturable cells were inoculated to natural (non-pasteurized) and pasteurized soils in order to examine their culturability and recovery. Exposing the cells to $20 \mu \mathrm{M} \mathrm{CuSO}_{4}$ produced transitory non-culturable cells, which exhibited a remarkable recovery in culturability after incubation in the solution for $36 \mathrm{~h}$, reaching a density near the initial level by $108 \mathrm{~h}$. To determine whether such non-culturable cells actually "resuscitated" or multiplied after adapting to $\mathrm{Cu}$ toxicity, growth curves were constructed in order to contrast the rates of increase in culturable cell numbers between $\mathrm{Cu}$-stressed or non-stressed inocula. Additionally, fresh non-stressed cells were exposed to $\mathrm{CuSO}_{4}$ in the presence of nalidixic acid by adding the antibiotic at different times after the onset of $\mathrm{Cu}$ stress to verify any cell multiplication during the population increase. The results revealed that the non-culturable cells surviving $\mathrm{Cu}$ toxicity adapted very quickly to $\mathrm{Cu}$ and began multiplying within $12 \mathrm{~h}$, because only the $\mathrm{Cu}$-stressed cells that were increasing in the exponential growth phase, but not those in the stationary phase, were killed by the antibiotic. Such cells exhibited an apparent tolerance to this metal when inoculated to a freshly prepared solution of $\mathrm{CuSO}_{4}$, and also detoxified the ion in the solution in which they grew. The presence of nutrients greatly counteracted the effect of $\mathrm{Cu}$ in water microcosms, since culturable cells were detected and increased in number even when exposed to $40 \mu \mathrm{M}$ $\mathrm{CuSO}_{4}$. In contrast, when inoculated to non-pasteurized soil, $\mathrm{Cu}$-stressed cells showed no such recoveries. However, when the soil was pasteurized before inoculation or added with nutrients, culturable cells were recovered and increased in number. This indicates that increased nutrient availability in soil allows $\mathrm{Cu}-$ stressed cells to quickly overcome the stress and increase in culturable populations.
\end{abstract}

Key words: Ralstonia solanacearum, non-culturable cells, adaptation to copper, survival, detection

\section{INTRODUCTION}

The bacterial wilt pathogen, Ralstonia solanacearum (Race 1), is a widely distributed soil inhabiting bacterium and affects a wide variety of crops, representing a serious threat to crop production in the areas where the disease has been reported as well as in the areas free of the pathogen (17). Coupled with its wide host range, it is very difficult to

*Corresponding Author. Mailing address: United Graduate School of Agricultural Science, Tokyo University of Agriculture and Technology, 3-5-8 Saiwai-cho, Fuchu, Tokyo 183-8509, Japan.; Tel: +81-28-649-5421 Fax: +81-28-649-5401.; E-mail: sermoreira@ yahoo.com 
eliminate it from soil once established due to its great ability to survive in soil.

For detection of this pathogen, the most recent approaches utilize PCR-based detection methods due to their specificity, and relatively quick results. Various genus and species, or even biovar-specific primers, have been designed and employed in many studies involving detection and identification $(2,4,9,11$, $16,22,23,27,28,35,37)$. However, such an advanced technology is not always available for researchers in developing countries. Furthermore, PCR theoretically cannot distinguish virulent populations of the pathogen from less virulent or non-pathogenic populations, which include the severely stressed or inviable cells that are not capable of infecting host plants any longer (25). Thus, in these cases, a semi selective agar medium specifically developed for detection may still be useful providing circumstantial evidence for the presence of the pathogen due to its lower cost and availability for being used on site. As a matter of fact, such a medium as SMSA has been and still is recommended in Europe (33) and in South America (18). Ideally, both types of methods should be used simultaneously to achieve the best reliable detections.

Nonetheless, detection methods based on use of agar media also have disadvantages. Since these methods depend on culturability, the pathogen can not be detected if it does not grow on the medium for some reason. It is known that $\mathrm{Cu}$ is widely used to control not only fungal but also bacterial plant diseases (1), and it has been reported that the presence of $\mathrm{Cu}$ can induce non-culturable cells of $R$. solanacearum (20). In addition, it has been suggested that Viable-But-Non-Culturable (VBNC) cells of $R$. solanacearum may be involved in infection of tomato and potato $(20,41)$.

Given that the VBNC state of $R$. solanacearum can greatly complicate its detection by various means, a study of the physiological responses of the pathogen to stresses that induce this state is justified in order to precisely understand how and when non-culturable cells are induced under different environmental conditions. Such knowledge would be particularly valuable in predicting and anticipating the presence of non-culturable cells in soil or plant samples as well as understanding their ecology and importance for plant health (40). The objectives of this study were to examine the effects of $\mathrm{Cu}$ on activity and culturability of $R$. solanacearum, and to examine survival and recovery of non-culturable cells in distilled water as well as natural and pasteurized soil.

\section{MATERIALS AND METHODS}

\section{Strain and inoculum preparation}

The strain of $R$. solanacearum used in this study was the rifampicin-resistant spontaneous mutant strain 22R6, derived from strain MAFF301522 (race 1, biovar 3) obtained from the Gene Bank of the Japanese Ministry of Agriculture, Forestry and Fisheries, initially isolated from tomato. Before use, strain 22R6 was streaked on plates of BGT medium (36) supplemented with $50 \mu \mathrm{g} \mathrm{ml}^{-1}$ of rifampicin (Sigma Chemical Co., St. Louis, MO, USA) and incubated for $48 \mathrm{~h}$ at $28^{\circ} \mathrm{C}$ to obtain single colonies. The colonies were transferred onto plates of BGT medium without TZC (2,3,5-triphenyl tetrazolium chloride, Sigma Chemical Co., St. Louis, MO, USA) (BGA medium) and incubated for $48 \mathrm{~h}$ at $28{ }^{\circ} \mathrm{C}$. After incubation, cells were suspended in sterile distilled water to prepare inocula with desired cell concentrations according to their turbidity at $590 \mathrm{~nm}$ measured with a Biolog turbidimeter (Biolog, Inc, Hayward, CA, USA).

\section{$\mathrm{Cu}$ treatment for induction of non-culturable cells}

Two and a half milliliters of the cell suspension $\left(\mathrm{OD}_{590}=\right.$ 0.5; approx. 8.0 $\log \mathrm{CFU} \mathrm{ml}{ }^{-1}$ ) dispensed into triplicate tubes were mixed with an equal volume of a filter sterilized $\mathrm{CuSO}_{4}$ solution to obtain the desired final concentration of $\mathrm{CuSO}_{4}(20$ and $40 \mu \mathrm{M})$ in the mixture. These concentrations were chosen after a series of preliminary tests on the responses of 22R6 to $\mathrm{Cu}$ stress (data not shown), which showed that recovery in 
culturable cell numbers was observed typically at $20 \mu \mathrm{M}$ $\mathrm{CuSO}_{4}$. Sterile distilled water was mixed with the cell suspension for the control without $\mathrm{CuSO}_{4}$. The tubes were incubated without shaking at $28^{\circ} \mathrm{C}$.

\section{Examination of non-culturable cells}

Cell density of strain 22R6 was enumerated in three different parameters every $12 \mathrm{~h}$ : (a) the total cell counts, (b) the number of culturable cells, and (c) percentage actively respiring cells. The total cell counts represent the numbers of all intact cells regardless of their viability and culturability. The number of culturable cells denotes colony forming units (CFU) enumerated on an agar medium. Actively respiring cells represent those having a functional electron transport system capable of oxidizing NADH or NADPH. (a) Enumeration of total cell counts: A Bacterial Counting Chamber (Sunlead Glass Co., Saitama, Japan) was used to enumerate the total cell counts, by optimizing the manufacturer's instructions. Briefly, a few drops (approx. $25 \mu \mathrm{l}$ ) of a sample cell suspension were pipetted onto the chamber, which then was mounted and observed under a light microscope at a magnification of $600 \mathrm{X}$. Cells in 40 squares of $50 \mu \mathrm{m} \times 50 \mu \mathrm{m}$ were counted, and the cell count was expressed as the logarithm of cell numbers per milliliter. (b) Enumeration of culturable cells: The number of culturable cells was determined by dilution plating on selective BGT medium supplemented with $50 \mathrm{mg} \mathrm{ml}^{-1}$ of rifampicin, and incubating the plates at $28^{\circ} \mathrm{C}$. Colonies of $22 \mathrm{R} 6$ developing on this selective medium, verified by their colony morphology to be typical of $R$. solanacearum, were enumerated after $2-3$ days, and the number of culturable cells was expressed as the logarithm of CFU per milliliter. The detection limit was $1.0 \mathrm{log}$ $\mathrm{CFU} \mathrm{ml} \mathrm{m}^{-1}$, and the value of $1 \log \mathrm{CFU} \mathrm{ml} \mathrm{ml} \mathrm{ml}^{-1}$ was used for samples below the limit of detection. (c) Determination of percentage of actively respiring cells: Reduction of an artificial electron acceptor, $2-(\mathrm{p}-$ iodophenyl $)-3-(\mathrm{p}-$ nitrophenyl $)$ - 5 - phenyl tetrazolium chloride (INT, Sigma Chemical Co., St. Louis, MO, USA), used by Fukui et al. (19) to measure metabolic activity of pseudomonads in sugar beet spermosphere, was employed with some modifications. The bacterial suspension to be assayed $(100 \mu \mathrm{l})$ was mixed with an equal volume of filtered-sterilized INT solution $\left(0.5 \mathrm{mg} \mathrm{ml}^{-1}\right.$ in $50 \mathrm{mM}$ Tris buffer at $\mathrm{pH} 7.5$ ), and incubated at room temperature on a rotary shaker at 50 r.p.m. in the dark for $1 \mathrm{~h}$. After incubation, $50 \mu \mathrm{l}$ of $18 \%$ formaldehyde were added to the suspension to stop the reaction, and the mixture was stored overnight at $4{ }^{\circ} \mathrm{C}$. Droplets of this suspension were placed on a water agar (WA) plate and then air-dried. These sections were then cut out and mounted on a glass slide with a cover slip and observed under the light microscope at a magnification of 1500X. For each replicate tube, more than 400 cells were counted and the percentage of INT - positive cells (i.e. cells with a visible INT formazan crystal inclusion) was determined (with three or four replicates), yielding a total of more than $1200-1600$ cells counted per sample. Since the data for total cell numbers enumerated visually were available in pairs with the corresponding data for percentage INT - positive cells, the numbers of actively respiring cells were extrapolated and expressed as the logarithm of cells per milliliter.

The effect of different concentrations of $\mathrm{CuSO}_{4}(5,10,20$ and $40 \mu \mathrm{M}$ ) on culturability of strain 22R6 was evaluated following the protocol described previously. A control treatment without $\mathrm{CuSO}_{4}$ was also included in this trial. This range of concentrations was used because it reflects successive 2-fold dilutions of the concentration that induced total loss of culturability $(40 \mu \mathrm{M})$ and the concentration that induced the recovery observed initially $(20 \mu \mathrm{M})$. For this test, only culturability was determined every $12 \mathrm{~h}$ by dilution plating during incubation at $28^{\circ} \mathrm{C}$.

\section{Survival of Cu-stressed cells in soil microcosms as compared to survival in water}

Upland loam soil (Haplic Andosols) without any histories of previous cropping for years was collected from a field in the University Farm of Utsunomiya University (Mooka, Tochigi). 
Some soil properties were as follows: $\mathrm{pH}\left(\mathrm{H}_{2} \mathrm{O}\right)=4.50$, $\mathrm{EC}=0.194 \mathrm{dS} \mathrm{m}^{-1}, \mathrm{CEC}=36.75 \mathrm{cmol}_{\mathrm{c}} \mathrm{Kg}^{-1}$ dry soil, total $\mathrm{C}=$ $112.62 \mathrm{~g} \mathrm{Kg}^{-1}$ dry soil, total $\mathrm{N}=6.50 \mathrm{~g} \mathrm{Kg}^{-1}$ dry soil, $\mathrm{C} / \mathrm{N}=$ 17.33 (Hirai, H., personal communication). The original $\mathrm{Cu}$ content of the soil was the following: Total $\mathrm{Cu}=52.65 \mathrm{mg} \mathrm{Kg}$ ${ }^{1}$ dry soil, soluble $\mathrm{Cu}_{(0.1 \mathrm{M} \mathrm{HCl})}=0.17 \mathrm{mg} \mathrm{Kg}^{-1}$ dry soil (26).

Composite soil samples were collected from approx. 10 random locations at a given site in the field to a depth of $10-$ $15 \mathrm{~cm}$, and transported to the campus. After lumps of soil were pulverized by crushing them with a clean shovel, the soil was passed through a $2.0-\mathrm{mm}$ sieve to homogenize and stored in 50-L plastic containers with plastic lids that allowed aeration, in a cool, shady place to maintain soil moisture.

The inocula used were the cells of 22R6 taken freshly from BGA medium and those exposed to 20 or $40 \mu \mathrm{M}$ of $\mathrm{Cu}$, by mixing the cell suspension prepared at approx. 8.0 $\log \mathrm{CFU}$ $\mathrm{ml}^{-1} 4 \mathrm{~h}$ prior to inoculation with an equal volume of $\mathrm{CuSO}_{4}$ solution at 0,40 or $80 \mu \mathrm{M}$. The inoculum cell suspensions were added to the soil microcosms directly to wet up the soil. Immediately prior to inoculation, the inocula were enriched with peptone and glucose to obtain a concentration of $0.2 \%$ for each nutrient in soil water. The inocula without addition of the nutrients were used as the controls.

Soil microcosms were prepared as follows: Samples of $100 \mathrm{~g}$ of soil (with its water content pre-determined) were placed into 93-mm-diameter plastic cups (approx. 300-ml capacity). Then, $5 \mathrm{ml}$ of each inoculum suspension were poured over the soil, and the cup was gently tapped to level the soil surface. If necessary, additional distilled water was added to the suspension to achieve the soil water content $(37 \%)$ equivalent to $-10 \mathrm{KPa}$ in the soil microcosms. Triplicate soil microcosms were prepared for each treatment. To maintain soil moisture and avoid anaerobic conditions during incubation, the cups were covered with screw-capped lids having several holes that were covered with oxygen-permeable $\left(260 \mathrm{ml} \mathrm{m}^{-2} \mathrm{~h}^{-1}\right.$ at 1 atm, $30^{\circ} \mathrm{C}$ ) parafilm (Novix-II, Asahi Technoglass, Tokyo, Japan). The microcosms then were incubated at $28^{\circ} \mathrm{C}$, and the numbers of CFU in the soil were determined after $0,3,7$ and 14 days of incubation by the method described below.

For the enumeration of culturable cells in soil, five grams of wet soil were sampled from the soil microcosm and suspended in $95 \mathrm{ml}$ of distilled water. The soil suspension was mixed well by shaking on a rotary shaker for $30 \mathrm{~min}$. at 75 r.p.m. to homogenize soil particles thoroughly, and dilutionplated on BGT medium supplemented with $50 \mu \mathrm{g} \mathrm{ml}^{-1}$ of rifampicin and $100 \mu \mathrm{g} \mathrm{ml}^{-1}$ of cycloheximide (Sigma Chemical Co., St. Louis, MO, USA). After 48 hours of incubation at 28 ${ }^{\circ} \mathrm{C}$, typical $R$. solanacearum colonies were counted, and the numbers of culturable cells were expressed in log CFU per gram of dry soil. The detection limit in this assay was $2.5 \log$ CFU $g^{-1}$ dry soil, and the value of $2 \log$ CFU $g^{-1}$ dry soil was used for the data below the detection limit.

A comparative test was also employed simultaneously in distilled water by using the same inocula inoculated into the soil microcosms. To $5 \mathrm{ml}$ of each $\mathrm{Cu}$-treated inoculum cell suspension dispensed in triplicates in the test tubes, $1 \mathrm{ml}$ of 1/10-strength BG broth was added as the nutrient source. For the controls, $1 \mathrm{ml}$ of distilled water was added. The tubes then were capped and incubated at $28^{\circ} \mathrm{C}$. The number of CFU was determined by dilution plating on BGT medium supplied with rifampicin after $0,1,2,3,5$ and 7 days of incubation.

A separate experiment was also made with pasteurized soil microcosms. Twenty four hours before use, soil was heated in a water bath at $55^{\circ} \mathrm{C}-65^{\circ} \mathrm{C}$ or at $75^{\circ} \mathrm{C}-85^{\circ} \mathrm{C}$ for $30 \mathrm{~min}$. to be pasteurized. These temperatures were chosen according to the differential sensitivity to heat manifested by fungi and bacteria. It has been reported that soil fungal populations decrease at lower temperatures than bacterial populations (8, 15). Accordingly, the first soil pasteurization temperature was mainly directed to reduce fungal populations and the second to reduce bacterial populations. The triplicate microcosms were prepared with these pasteurized soils as well as non-pasteurized natural soil using only $\mathrm{Cu}$-stressed inocula exposed to 20 or 40 $\mu \mathrm{M}$ of $\mathrm{Cu}$. The test was done as described above. 


\section{Statistical analysis}

Data of survival experiments using natural and pasteurized soils were analyzed by ANOVA with a factorial completely randomized design. $\mathrm{Cu}$ concentration, presence or absence of nutrients and, when applicable, pasteurization of soil were considered as the main effect factors and sampling day was considered a repeated measures factor. When significant differences were detected by the ANOVA, means were compared with the protected LSD test.

\section{RESULTS}

\section{$\mathrm{Cu}$ treatment and culturability of $\mathrm{Cu}$-stressed cells}

When the cells of $22 \mathrm{R} 6$ were exposed to $20 \mu \mathrm{M} \mathrm{CuSO}$, no CFU was detected by either $12 \mathrm{~h}$ or $24 \mathrm{~h}$. After $36 \mathrm{~h}$, however, $1.97 \log \mathrm{CFU} \mathrm{ml}{ }^{-1}$ was detected and thereafter CFU increased progressively over time, reaching nearly the initial CFU by $108 \mathrm{~h}$ (Fig. 1A). The percentage of INT-positive cells also dropped sharply but only to approx. $30 \%$ of the initial cell numbers by $12 \mathrm{~h}$, and remained at about a half of the corresponding total cell number (Fig. 1B). Throughout the incubation, the total cell number remained nearly constant. Therefore, after $108 \mathrm{~h}$ of incubation, the number of CFU was only $0.6 \log$-unit lower than the log number of INT-positive cells (Fig. 1B). In contrast, exposure to $40 \mu \mathrm{M} \mathrm{CuSO}_{4}$ clearly showed a long-lasting toxic effect of $\mathrm{Cu}$ on strain 22R6. By 12 hours, no CFU was detected but about $25 \%$ of the cells remained INT-positive cells (Fig. 1C). The total cell number remained above $\log 8.0$ cells $\mathrm{ml}^{-1}$ throughout the incubation.
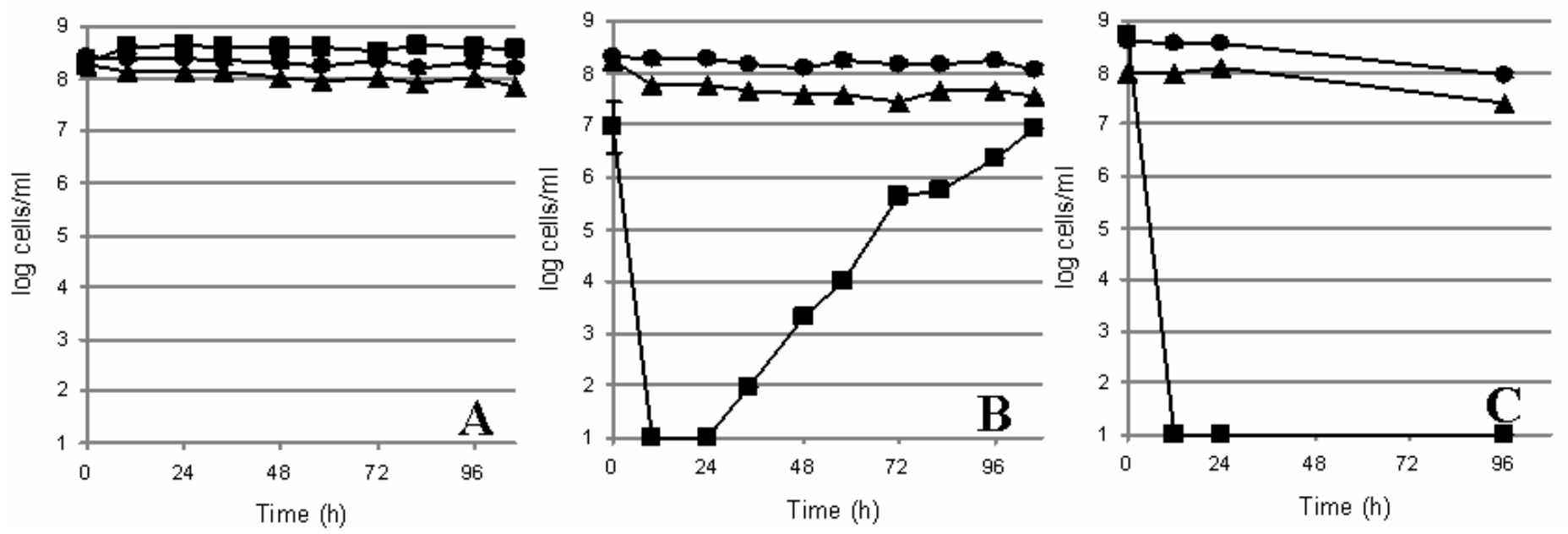

Figure 1. Effects of: A) $0 \mu \mathrm{M}$, B) $20 \mu \mathrm{M}$ and C) $40 \mu \mathrm{M} \mathrm{CuSO}_{4}$ on cell density of strain $22 \mathrm{R} 6$ in distilled water, enumerated in terms of the total cell number (circles), CFU (squares) and INT-active cells (triangles). Percentage INT-active cells (data not shown) was extrapolated to the number of INT-active cells. Each data point represents a mean of three replicates and error bars represent standard deviations. The detection limit for CFU was $1.0 \log \mathrm{CFU} \mathrm{ml}{ }^{-1}$, and data below the limit were plotted at $1 \log$ $\mathrm{CFU} \mathrm{ml}{ }^{-1}$.

Effect of different concentrations of $\mathrm{Cu}$ on culturability and recovery of $\mathrm{Cu}$-stressed cells

The effect of $\mathrm{Cu}$ on culturability was dependent on $\mathrm{Cu}$ concentration (Fig. 2). The decline in culturable cell numbers
$12 \mathrm{~h}$ after inoculation was observed in all treatments but it was less pronounced at 5 and $10 \mu \mathrm{M} \mathrm{CuSO}$. As before, the subsequent recovery of culturable cell numbers was not observed for the inoculum exposed to $40 \mu \mathrm{M} \mathrm{CuSO}_{4}$. In none 
of the treatments where recovery was observed did the final culturable cell number exceed the initial population size; both 5 and $10 \mu \mathrm{M}$-stressed cells approached approx. $\log$ 8.0 CFU ml ${ }^{-1}$

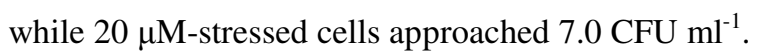

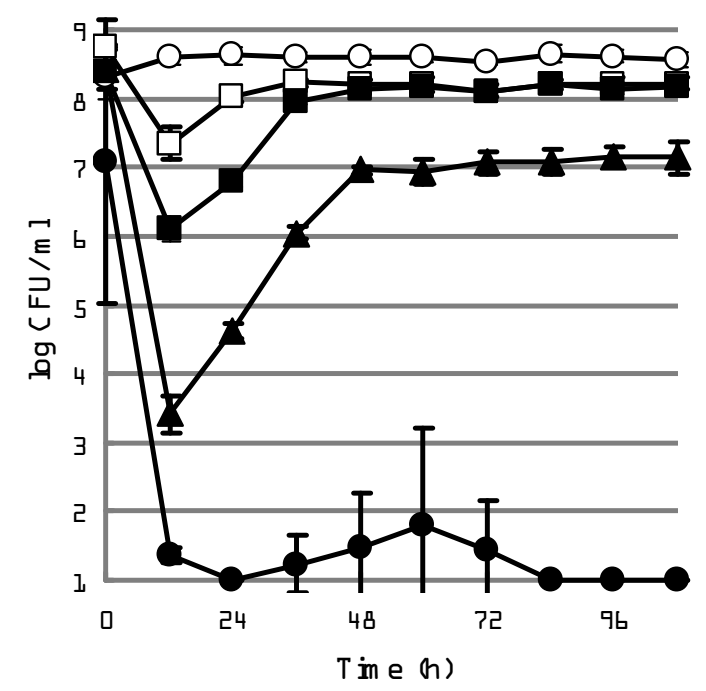

Figure 2. Effect of different concentrations of 0 (white circles), 5 (white squares), 10 (black squares), 20 (black triangles) and 40 (black circles) $\mu \mathrm{M}$ of $\mathrm{CuSO}_{4}$ on culturability of strain 22R6. Each data point represents a mean of three replicates and error bars represent standard deviations.

\section{Characterization of recovered culturable cells following $\mathrm{Cu}$ stress}

\section{Resistance to $\mathrm{Cu}$ of culturable recovered $\mathrm{Cu}$-stressed} cells: In order to examine if $\mathrm{Cu}$-adapted cells survive the initial stress of $\mathrm{Cu}$ treatment and multiply in the $20 \mu \mathrm{M} \mathrm{CuSO}$ solution, the cells recovered from this solution and fresh cells taken from $48 \mathrm{~h}$-old BGA plates were inoculated in triplicates to newly prepared solutions of $\mathrm{CuSO}_{4}$ by adjusting the concentrations of $\mathrm{CuSO}_{4}$ to $10 \mu \mathrm{M}$ and $20 \mu \mathrm{M}$. The culturability of the cells was monitored by dilution-plate counting at various times. When actively growing cells taken from BGA medium and those cells that had been exposed to 20 $\mu \mathrm{M} \mathrm{CuSO}{ }_{4}$ over $108 \mathrm{~h}$ were transferred to a freshly made solution of $20 \mu \mathrm{M} \mathrm{CuSO}$ and incubated at $28^{\circ} \mathrm{C}$, most of the fresh unstressed cells became undetectable by dilution plating by $12 \mathrm{~h}$ (Fig. 3). In contrast, previously exposed cells did not show any significant drop during the entire period of incubation.

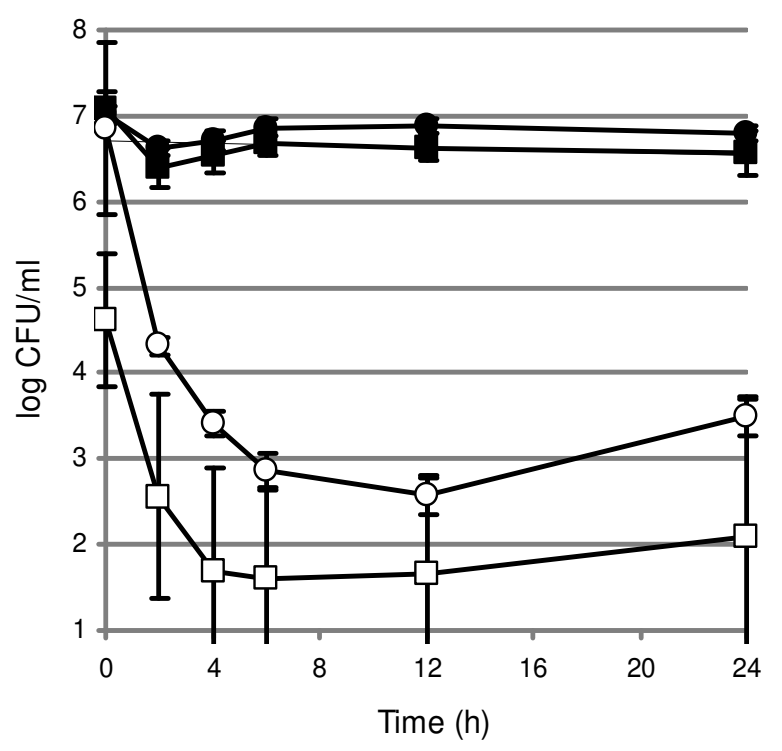

Figure 3. Dynamics of fresh unstressed cells (white symbols) and $\mathrm{Cu}$-stressed recovered cells (black symbols) of 22R6 inoculated into newly prepared $\mathrm{Cu}$ solutions. The concentrations used were 10 (circles) and 20 (squares) $\mu \mathrm{M}$ of $\mathrm{CuSO}_{4}$. Each data point represents a mean of three replicates and error bars represent standard deviations.

Increase in culturable cell numbers in distilled water and under Cu stress: In order to construct growth curves for culturable population in water, an initial cell suspension of approx. $\log 4.0 \mathrm{CFU} \mathrm{ml}{ }^{-1}$ and four serial 4-fold dilutions of the suspension were prepared in distilled water. The suspensions were incubated at $28^{\circ} \mathrm{C}$ and culturability was determined periodically. For the curves in $20 \mu \mathrm{M} \mathrm{CuSO}_{4}$, equal volumes of $40 \mu \mathrm{M} \mathrm{CuSO}$ and fresh inocula were mixed in order to obtain cell suspensions of different concentrations and culturable cells were counted every $12 \mathrm{~h}$ by dilution plating. 
The curves showing the dynamics of culturable populations of strain 22R6 in distilled water and in $20 \mu \mathrm{M} \mathrm{CuSO}_{4}$ with time are shown in Fig. 4A and 4B, respectively. Additionally, the initial numbers of visually verifiable cells under the light microscope were determined in order to compare them with the maximum CFU numbers attained by the increase of culturable cells (Fig. 4). In distilled water, and despite a different initial cell density in each water microcosm, the culturable cell numbers in the five microcosms reached a cell density near log $7.0 \log \mathrm{CFU} \mathrm{ml}{ }^{-1}$ after $48 \mathrm{~h}$ of incubation, and these culturable cell densities did not decrease until the end of incubation. These final CFU numbers were well above the theoretical maximum of initial total cell number estimated by visually counting the cells under the microscope $\left(<\log 4.0\right.$ cells $\left.\mathrm{ml}^{-1}\right)$ (Fig. 4A). The doubling time in culturable populations was calculated by the equation: $\log 2\left(t_{2}-t_{1}\right) /\left(\log N_{2}-\log N_{1}\right)$, where $t_{1}$ and $t_{2}$ are the earliest and latest time points, respectively, during $\log$ growth phase; and $\mathrm{N}_{1}$ and $\mathrm{N}_{2}$ are the corresponding numbers of CFU per milliliter. The doubling times of these growing culturable cells in distilled water were calculated to be between $1.86 \mathrm{~h}$ and $2.32 \mathrm{~h}$. For the $\mathrm{Cu}$-stressed inocula, only the highest initial concentration inoculum (approx. $\log 8.0 \mathrm{CFU} \mathrm{m} \mathrm{m}^{-1}$ ) retained culturability and showed the typical initial decline and subsequent increase of culturable cells after $24 \mathrm{~h}$ of incubation (Fig. 4B). In this case, the final CFU number $\left(\log 7.5 \mathrm{CFU} \mathrm{ml}^{-1}\right)$ was lower than the initial total cell number counted under the microscope (log 8.1 cells $\mathrm{ml}^{-1}$ ). The "doubling time" calculated for these increasing culturable cells in the $\mathrm{Cu}$ solution was $2.83 \mathrm{~h}$. The inocula at lower initial concentrations $\left(<\log 7.7 \mathrm{CFU} \mathrm{ml}^{-1}\right)$ did not show any recovery or adaptation following $\mathrm{Cu}$ stress and culturable cells were not detectable even at $12 \mathrm{~h}$ after stress onset (Fig. 4B).
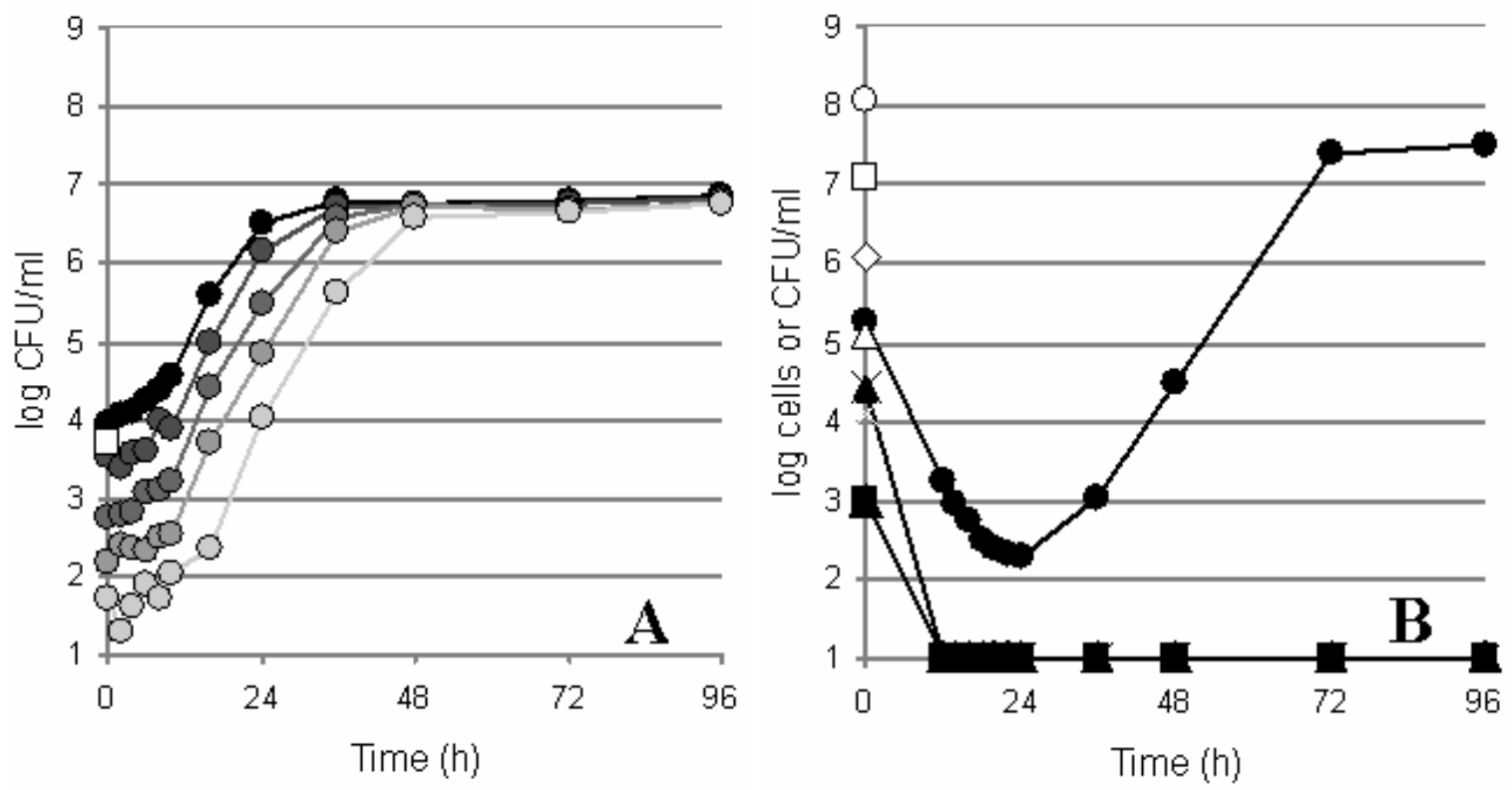

Figure 4. A) Growth curves of 4-fold serially diluted non-stressed inocula of strain 22R6 in distilled water. The inoculum with the highest initial cell density was obtained after a $10^{5}$-dilution of an $\mathrm{OD}_{590}=0.5$ cell suspension, which was verified by visual enumeration to contain $8.72 \log$ cells $\mathrm{ml}^{-1}$. The theoretical initial total cell number for the highest dilution indicated by a white square was $\log 3.72 \mathrm{CFU} \mathrm{ml}^{-1}$. B) Effect of $20 \mu \mathrm{M}$ of $\mathrm{Cu}$ on culturability (black symbols) of 22R6 adjusted to different initial inoculum cell densities. The initial total cell number of the inoculum at the highest cell density (white circle) was verified visually to be $8.08 \log$ cells $\mathrm{ml}^{-1}$, and the theoretical initial cell numbers for the diluted inocula are indicated with respective white symbols. The corresponding culturable populations are indicated with respective black symbols. 
Biological availability of $\mathrm{Cu}$ in the solution after recovery of $\mathrm{Cu}$-stressed cells: Biological availability or bioavailability of $\mathrm{Cu}$ in the context of this study is defined as the amount of $\mathrm{Cu}$ effectively acting upon strain 22R6 in contrast to the total amount of $\mathrm{Cu}$ present in the solution (molar concentration), since the biologically unavailable portion may be chelated or otherwise bound to extracellular molecules.

With the objective of clarifying the biological availability of $\mathrm{Cu}$ in the $20 \mu \mathrm{M} \mathrm{CuSO}{ }_{4}$ solution following the observed

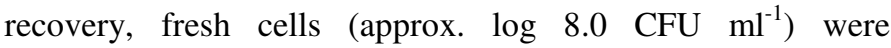
inoculated to three triplicate sets of tubes containing equal volume of solutions of $\mathrm{CuSO}_{4}$ to obtain final concentrations of 0, 20 and $40 \mu \mathrm{M}$ of $\mathrm{CuSO}_{4}$ in each triplicate set. After 1 week of monitoring culturability, the remaining suspensions were filter-sterilized and new fresh cells were inoculated into these remaining solutions. Culturable cells were then monitored by dilution plating. As observed earlier, culturable cell numbers decreased from approx. $\log 8.0 \mathrm{CFU} \mathrm{ml}^{-1}$ to $\log 2.6 \mathrm{CFU} \mathrm{ml}{ }^{-1}$ when the fresh cells were first exposed to $20 \mu \mathrm{M}$ of $\mathrm{Cu}$ (Fig.
5A). The subsequent recovery of culturable cell number after $24 \mathrm{~h}$ was also observed. At $40 \mu \mathrm{M} \mathrm{CuSO}{ }_{4}$ the total loss of culturable cells was observed as previously. After $96 \mathrm{~h}$, strain 22R6 cells at $20 \mu \mathrm{M} \mathrm{CuSO}{ }_{4}$ had a final culturable cell concentration 10-fold lower than that of the control without $\mathrm{Cu}$ stress. The control showed a slight increase in culturable cell numbers during the first $24 \mathrm{~h}$ and thereof no evident variation throughout the experiment (Fig. 5A).

When fresh cells were then inoculated into filter-sterilized solutions from the initial cell suspensions, the bioavailability of

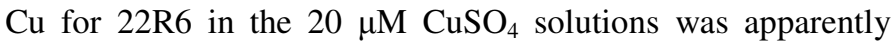
much less, and comparable to that of the distilled water control since no decrease in culturability was observed (Fig. 5B). At 40 $\mu \mathrm{M} \mathrm{CuSO}$, on the other hand, the culturable cell number decreased after $9 \mathrm{~h}$ to $2.94 \log \mathrm{CFU} \mathrm{ml}{ }^{-1}$ and then increased to the level of approx. $\log 7.5 \mathrm{CFU} \mathrm{ml}^{-1}$ after $46 \mathrm{~h}$ (Fig. 5B). Also in this case, the final number of culturable cells did not exceed the initial number.
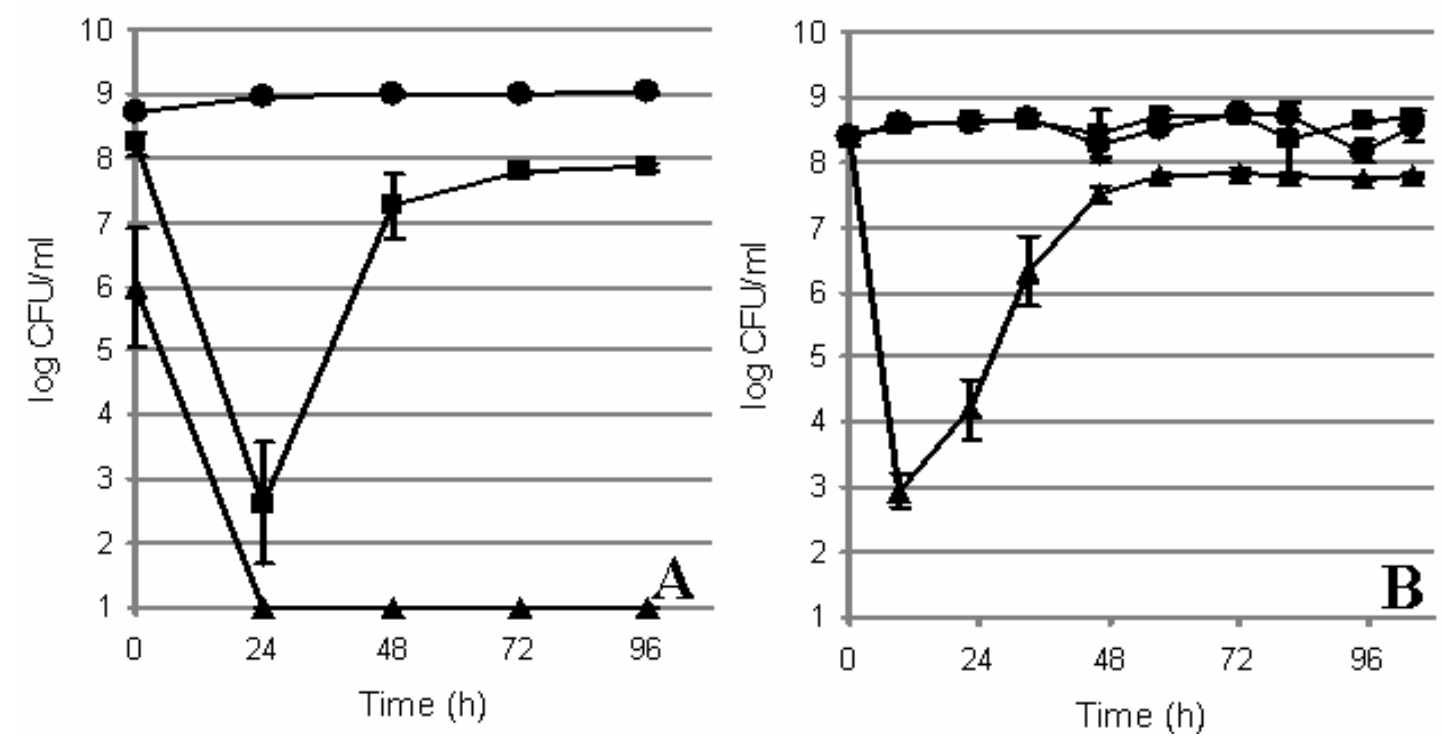

Figure 5. Effect of incubation in $\mathrm{Cu}$ solutions on culturability of fresh cells of strain $22 \mathrm{R} 6$ inoculated to the same solutions after filter sterilization. A) The strain was first incubated in distilled water (circles), and solutions of CuSO4 at $20 \mu \mathrm{M}$ (squares) or 40 $\mu \mathrm{M}$ (triangles) and incubated for $96 \mathrm{~h}$. B) The fresh cells were then inoculated to the same solutions after they were filtered to remove the previous cells. Each data point represents a mean of three replicates and error bars represent standard deviations. 
Effect of nalidixic acid on the recovery of $\mathrm{Cu}$-stressed cells: Since the nature of the observed recovery of culturability in water was not obvious after the previous experiments, nalidixic acid was used to discriminate "resuscitating" cells from multiplying $\mathrm{Cu}$-adapted cells that might have arisen from the original population. Nalidixic acid inhibits DNA replication by blocking the activity of DNA-gyrase, and the hypothesis tested was as follows: If the increase in culturable cells was due to "resuscitation" from non-culturable cells, nalidixic acid should not stop or influence this population increase in any manner. But if cell division and hence cell multiplication were involved in the increase, nalidixic acid should affect the increase in an observable manner. A similar approach has been previously used in $R$. solanacearum in order to inhibit multiplication of viable cells (3, 20).

Fresh cell inoculum was prepared as explained previously and inoculated into triplicate tubes with an equal volume of $\mathrm{CuSO}_{4}$ solutions in order to obtain final $\mathrm{Cu}$ concentrations of either 20 $\mu \mathrm{M}$ or $40 \mu \mathrm{M}$. Nalidixic acid was added to a final concentration of $25 \mu \mathrm{g} \mathrm{ml}^{-1}$ at either $0,12,24$ or $36 \mathrm{~h}$ after inoculation. The concentration of the antibiotic was determined in preliminary tests as the minimum concentration capable of inhibiting growth of 22R6 cells. Addition of nalidixic acid at different times after inoculation and $\mathrm{Cu}$-stress onset was tested in order to observe the effect of the antibiotic on cells at different stages of the population increase. Triplicate tubes of control treatments without nalidixic acid were also prepared for each $\mathrm{Cu}$ concentration.
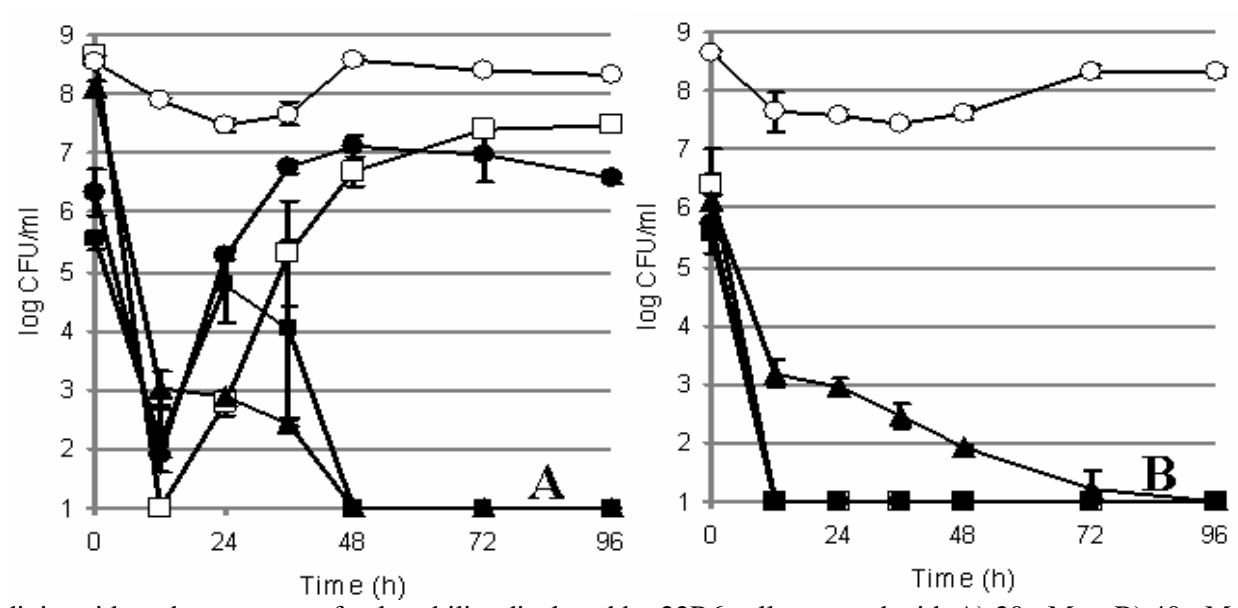

Figure 6. Effects of nalidixic acid on the recovery of culturability displayed by $22 \mathrm{R} 6$ cells stressed with A) $20 \mu \mathrm{M}$ or B) $40 \mu \mathrm{M}$ of $\mathrm{CuSO}_{4}$. The antibiotic was added either at the same time of stress onset (white circles) or at either $12 \mathrm{~h}$ (black triangles), $24 \mathrm{~h}$ (black squares), or $36 \mathrm{~h}$ (black circles) after stress onset. The control treatments (white squares) consisted of stressed cells without any addition of the antibiotic. Each data point represents a mean of three replicates and error bars represent standard deviations.
The effect of nalidixic acid was clearly more dependent on the time of antibiotic addition than on $\mathrm{Cu}$ concentration. When added at the same time of inoculation and the stress onset, a remarkable masking of the $\mathrm{Cu}$ stress at both concentrations was observed as the reduction of culturable cells was negligible (Fig.

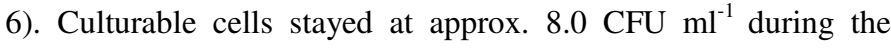
whole duration of the experiment. When nalidixic acid was added into $20 \mu \mathrm{M} \mathrm{CuSO}_{4}$ (Fig. 6A) at $12 \mathrm{~h}$ after inoculation, the increase of culturable cells observed in the control and in previous experiments was completely prevented, resulting in a drop in culturable population below detection levels by $48 \mathrm{~h}$. Addition of nalidixic acid at $24 \mathrm{~h}$ also interrupted the increase of culturable cells and resulted in a non-culturable population by $48 \mathrm{~h}$. When the antibiotic was added at $36 \mathrm{~h}$ however, its effect was indiscernible. Culturable cells had already recovered and reached a near-maximum number by the time of the antibiotic addition, but only a small reduction in culturable cell numbers to $6.57 \mathrm{CFU} \mathrm{ml}{ }^{-1}$ was observed at $96 \mathrm{~h}$. At $40 \mu \mathrm{M} \mathrm{CuSO}_{4}$ (Fig. 6B), on the other hand, the addition of nalidixic acid at $12 \mathrm{~h}$ did not allow either the decline of culturable cell numbers below detection at $12 \mathrm{~h}$, as it occurred in the control and in previous experiments, or any possible recovery from the stress. The culturable cell number dropped to approx. 3.0 CFU ml ${ }^{-1}$ at $12 \mathrm{~h}$ and steadily decreased until eventually becoming undetectable by the end of the experiment. The antibiotic added at $24 \mathrm{~h}$ or $36 \mathrm{~h}$ after inoculation did not affect the already undetectable cells stressed by $40 \mu \mathrm{M}$ $\mathrm{CuSO}_{4}$, which stayed undetected until the end of the experiment. 
Survival of $\mathrm{Cu}$-stressed cells in soil microcosms as compared to that in water: The previous experiments were all conducted in distilled water in order to isolate the effect of $\mathrm{Cu}$ on culturability of strain 22R6. Thus, the partial physiological characterization of some aspects of the cells with recovered culturability after $\mathrm{Cu}$ stress was performed without the interference of their response to nutrients or of other microbes present in the medium. However, it is natural to assume that these two factors could have significant roles in the ecology of these cells in natural environments. In order to test this hypothesis, experiments in which $\mathrm{Cu}$-stressed cells were inoculated into natural soil and distilled water in the presence of nutrients were executed. In addition, the influence of microorganisms present in soil was studied in an experiment in which natural soil and soil pasteurized at two different temperatures were inoculated with $\mathrm{Cu}$-stressed cells in the presence or absence of nutrients.

When the cells exposed to $\mathrm{CuSO}_{4}$ at 20 or $40 \mu \mathrm{M}$ were inoculated into natural soil, culturable populations remained low (near or less than $3.0 \log$ CFU g dry soil ${ }^{-1}$ ) throughout 14 days of incubation (Fig. 7B and 7C). When the inocula were enriched with nutrients, however, culturable populations increased dramatically; culturable populations for the cells treated with $20 \mu \mathrm{M} \mathrm{CuSO}$ were not significantly different from those for non-treated cells (Fig. 7A and 7B), and the populations for the cells treated at $40 \mu \mathrm{M}$ were only less than 1.0-log unit lower than those for the controls (Fig. 7A and 7C).

When the cells exposed to 20 or $40 \mu \mathrm{M}$ were incubated in distilled water at $28^{\circ} \mathrm{C}$, the culturable population again dropped sharply and was not detected after 1 day of incubation (Fig. 8B and $8 \mathrm{C}$ ). However, as observed in the previous experiments, the cells treated with $20 \mu \mathrm{M} \mathrm{CuSO}{ }_{4}$ regained culturability thereafter and rapidly increased in number to reach approx. 7.0 $\log$ CFU ml ${ }^{-1}$ by 5 days of incubation (Fig. 8B). Yet, such recovery and increase in culturable population were not observed for the cells treated with $40 \mu \mathrm{M}$ of $\mathrm{CuSO}_{4}$ (Fig. 8C). On the other hand, when both $\mathrm{Cu}$-treated inocula were enriched with nutrients, high numbers of culturable populations $(>7.0$ $\log \mathrm{CFU} \mathrm{ml}{ }^{-1}$ ) were detected after 3 days even though the populations initially dropped to some extent. When the cells were not treated with $\mathrm{Cu}$, culturable population remained at high levels (>8.5 log CFU ml ${ }^{-1}$ ) and nutrient enrichment had virtually no effects on the population (Fig. 8A).
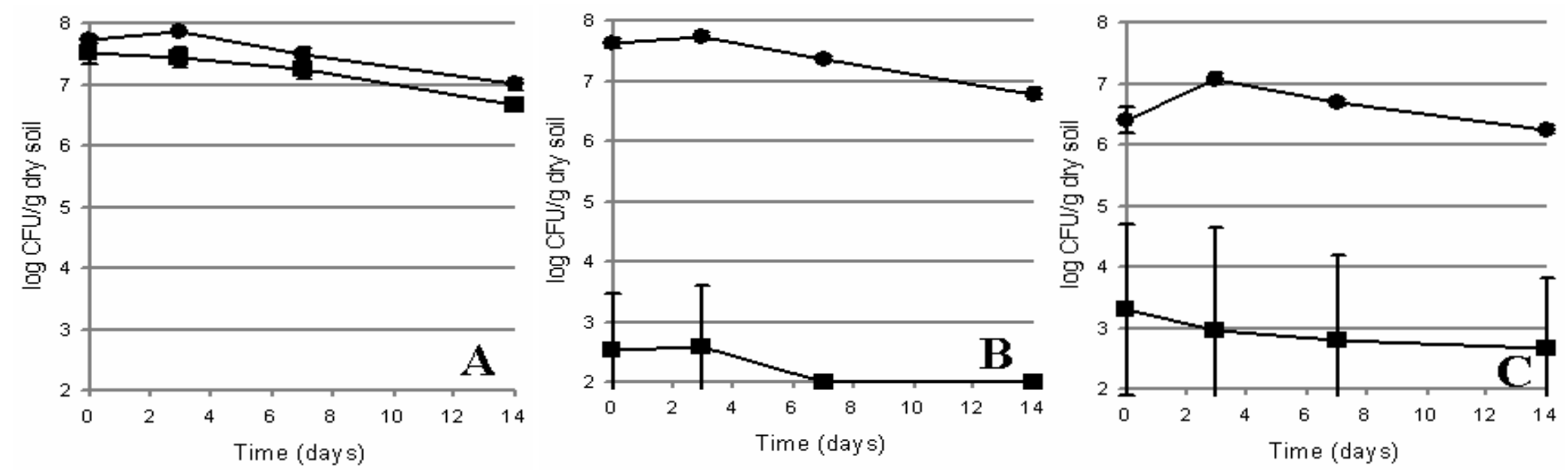

Figure 7. Growth patterns of: A) untreated 22R6 cells and the cells treated with B) $20 \mu \mathrm{M}$ and C) $40 \mu \mathrm{M}$ of $\mathrm{CuSO}_{4}$ in the presence (circles) and absence (squares) of nutrients in the natural soil microcosm. Each data point represents a mean of three replicates and error bars represent standard deviations. According to ANOVA, all effects $(\mathrm{Cu}$ treatment, presence of nutrients, and repeated measures) were significant $(\mathrm{P}=0.01)$ with three-way significant interaction. The LSD value $(\mathrm{P}=0.01)$ used to compare between all means was 0.31 . The detection limit was 2.5 log CFU g dry soil-1, and data below the limit were plotted at $2 \log$ CFU g ${ }^{1}$ dry soil. 

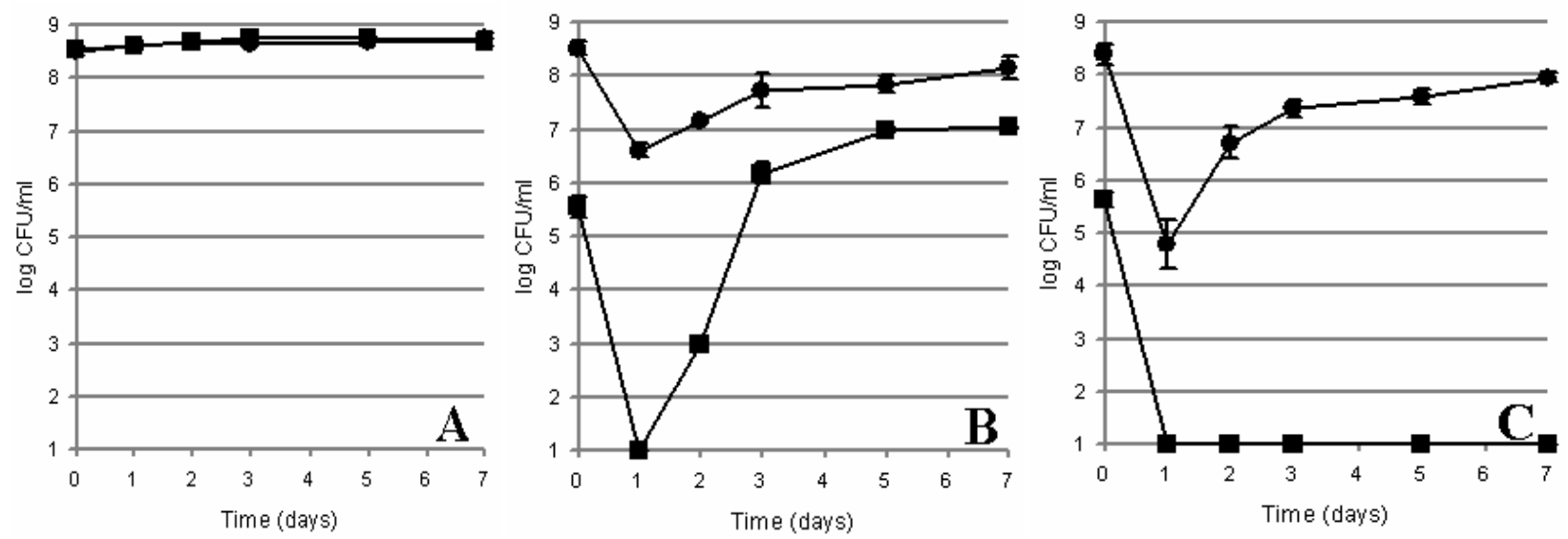

Figure 8. Growth patterns of: A) untreated 22R6 cells and the cells treated with B) $20 \mu \mathrm{M}$ and C) $40 \mu \mathrm{M}$ of $\mathrm{CuSO}_{4}$ in the presence (circles) and absence (squares) of nutrients in the water microcosm. Each data point represents a mean of three replicates and error bars represent standard deviations. According to ANOVA, all effects $(\mathrm{Cu}$ treatment, presence of nutrients, and repeated measures) were significant $(\mathrm{P}=0.01)$ with a two-way $(\mathrm{Cu}$ treatment and presence of nutrients) significant interaction. The LSD value $(\mathrm{P}=0.01)$ used to compare between all means was 1.42 . The detection limit was $1.0 \log \mathrm{CFU} \mathrm{m}{ }^{-1}$, and data below the limit were plotted at 1 log $\mathrm{CFU} \mathrm{ml}^{-1}$.

The data presented in Fig. 9 show the survival of cells stressed with $20 \mu \mathrm{M} \mathrm{CuSO}_{4}$ (Fig. 9A) or with $40 \mu \mathrm{M} \mathrm{CuSO}_{4}$ (Fig 9B) in natural soil and in the same soil pasteurized at $55^{\circ} \mathrm{C}$ - $65^{\circ} \mathrm{C}$ or at $75^{\circ} \mathrm{C}-85^{\circ} \mathrm{C}$. As observed previously, the $\mathrm{Cu}-$ stressed cells did not increase notably when inoculated to the non-pasteurized natural soil, but attained high culturable populations $\left(>8.0 \log \mathrm{CFU} \mathrm{ml}{ }^{-1}\right.$ ) when the same inocula were enriched with the nutrients. Soil pasteurization produced a more than 100-fold increase of culturable cells after 3 days in the soil inoculated with non-enriched inocula, regardless of the concentration of $\mathrm{Cu}$ in the soil. This effect of soil pasteurization was more pronounced when the soil was treated at $75^{\circ} \mathrm{C}-85^{\circ} \mathrm{C}$ than at $55^{\circ} \mathrm{C}-65^{\circ} \mathrm{C}$. The presence of nutrients in pasteurized soils caused the culturable numbers to be $2-3$ $\log$ units higher than the corresponding numbers for nonenriched inocula. This difference increased dramatically when using the natural non-pasteurized soil: the presence of nutrients considerably reduced the difference in culturable cell numbers between the pasteurized and natural soils for both concentrations of $\mathrm{Cu}$.
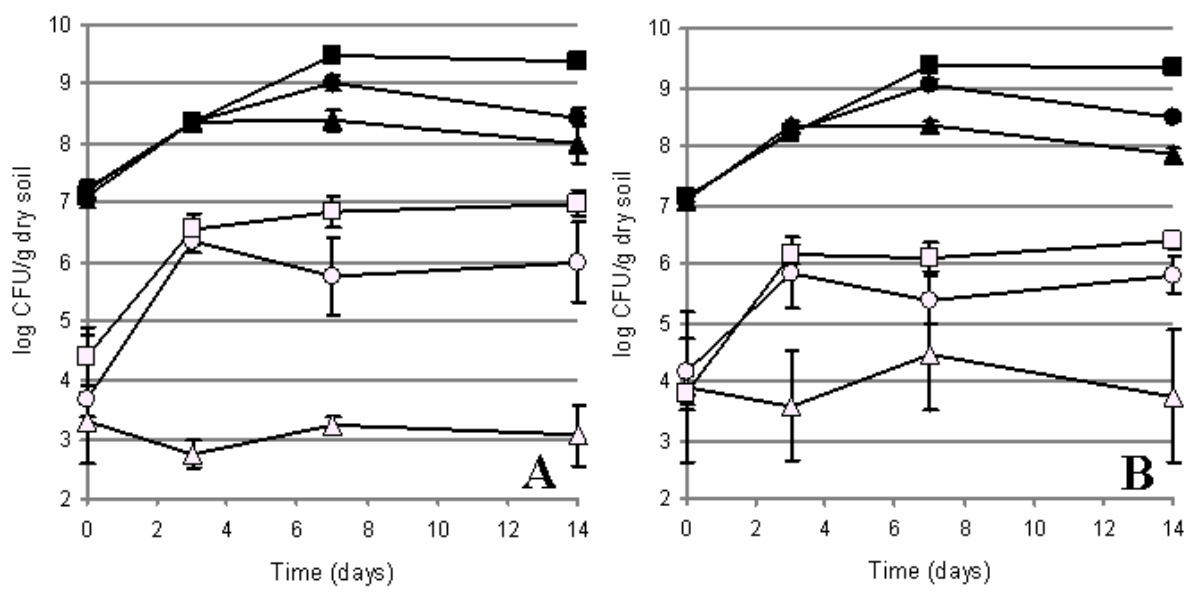

Figure 9. Growth patterns of 22R6 cells treated with: A) $20 \mu \mathrm{M}$ and B) $40 \mu \mathrm{M}$ of $\mathrm{CuSO}_{4}$ in the presence (black symbols) and absence (white symbols) of nutrients in natural soil (triangles) and in the same soil pasteurized at $55^{\circ} \mathrm{C}-65^{\circ} \mathrm{C}$ (circles) or $75^{\circ} \mathrm{C}-85^{\circ} \mathrm{C}$ (squares). Each data point represents a mean of three replicates and error bars represent standard deviations. According to ANOVA, the effects of soil pasteurization, presence of nutrient, and repeated measures were significant $(\mathrm{P}=0.01)$ with three way interaction. The LSD value $(\mathrm{P}=0.01)$ to compare between all means was 1.15. The detection limit was $2.5 \log$ CFU g dry soil-1, and data below the limit were plotted at $2 \log$ CFU g ${ }^{1}$ dry soil.

586 


\section{DISCUSSION}

This study revealed that $\mathrm{Cu}$-stressed cells of $R$. solanacearum induced by exposure to the borderline cytotoxic concentration of $\mathrm{Cu}$ were able to respond quickly to overcome the toxicity of $\mathrm{Cu}$ and multiply in the absence of external nutrients. When the cells were incubated in distilled water with $20 \mu \mathrm{M} \mathrm{CuSO}$, the $\mathrm{Cu}$-stressed cells once became nonculturable or nearly non-detectable but remained viable. Then, they soon showed a remarkable recovery in culturability in a matter of a day (Fig. 1B). Subsequently, the number of culturable cells increased and nearly reached the number of INT-positive cells.

The effect of $\mathrm{Cu}$ on strain 22R6 was apparently transient and dose-dependent (Fig. 2), providing an evidence for quick adaptation of the strain to this heavy metal. This suggests that $\mathrm{Cu}$-stressed cells may recover eventually even at higher $\mathrm{Cu}$ concentrations if incubated under different conditions. In fact, the cells exposed to $40 \mu \mathrm{M}$ of $\mathrm{Cu}$ were apparently not recovering in distilled water (Fig. $8 \mathrm{C}$ ), but quickly did so when enriched with nutrients. In contrast, Grey and Steck (20) were able to produce VBNC cells of $R$. solanacearum with concentrations of $\mathrm{CuSO}_{4}$ as high as $500 \mu \mathrm{M}$, but they did not report any recovery of culturability even at $5 \mu \mathrm{M}$. Van Overbeek, cited by Van Elsas et al. (40), reported that a strain of $R$. solanacearum biovar 2 resisted $\mathrm{Cu}$ concentrations up to $25 \mathrm{mM}$ for over 3 weeks. These differences may indicate that the $\mathrm{Cu}$ effect is also strain-dependent or such strains differed in nutritional status. It is clear also that the cells that had been exposed to $\mathrm{Cu}$ in this study were less sensitive in a freshly prepared $\mathrm{Cu}$ solution (Fig. 3), indicating that some mode of adaptation/tolerance was developing quickly. Thus, previous exposure(s) of some strains to $\mathrm{Cu}$ may explain the straindependent effect of $\mathrm{Cu}$. In fact, such adjustments are not unconceivable in bacteria. $\mathrm{Cu}$ is an important trace element but toxic at high concentrations due to an unspecific uptake system for heavy metals mediated by P-type ATPases (31). As a consequence, it requires what is thought to be a chromosomally encoded homeostasis system in bacteria, from which a plasmid-borne resistance mechanism may have evolved (13, 31).

Detoxification or chelation of $\mathrm{Cu}$ molecules is one likely mechanism by which $R$. solanacearum copes with its cytotoxic effect. It has been reported previously that siderophores, metal binding proteins, and even polysaccharides can bind to $\mathrm{Cu}$ and reduce its bioavailability (21). It has also been suggested that pseudomonads have the ability to compartmentalize $\mathrm{Cu}$ ions in the periplasm and the outer membrane (13). If this is the case, the concentration of biologically active $\mathrm{Cu}$ ions in the solution must decrease as the number of culturable cells increases during incubation. Thus, it seems valid to speculate that the recovery of culturability by strain 22R6 is a secondary effect of the reduced bioavailability of $\mathrm{Cu}$ in the solution. Once the amount of free $\mathrm{Cu}$ ions in the solution is reduced to a certain level by the aforementioned compartmentalization mechanism, some still viable cells can multiply and reflect in the recovery observed. To test this hypothesis, a 2-stage experiment was performed by reinoculating fresh cells to $\mathrm{Cu}$ solutions in which inoculated cells had previously recovered their culturability and then been removed (Fig. 5). As a result, $\mathrm{Cu}$ was apparently not much available in the filtrate anymore for the second inoculum. In contrast, toxicity of $\mathrm{Cu}$ was still evident if no recovery had taken place. In order to confirm that $\mathrm{Cu}$ is detoxified by the bacterium, a bio-sensor bacterial strain (30) genetically engineered to specifically react to $\mathrm{Cu}$ ions by expressing reporter genes may be an effective tool to measure and monitor the concentration of biologically active $\mathrm{Cu}$ in the culture, understood as the concentration capable of affecting bacterial metabolism as opposed to the $\mathrm{Cu}$ concentration that might not be all available to affect the cells.

INT by itself does not affect the viability of the cells, and the percentage of INT-positive cells remained constantly low (around 30\%) while the number of culturable cells increased progressively (Fig. 1B). This indicates that the metabolic 
activity, represented by the percentage of respiring cells, did not increase during recovery of culturability, implying that multiplication of the cells was not involved in the event. However, the latter event cannot be ruled out, since the number of culturable cells in the $\mathrm{Cu}$ solution was nearly equal to the number of INT-positive cells after $108 \mathrm{~h}$ of incubation, and the percentage of INT-positive cells decreased even in the absence of $\mathrm{Cu}$ (data not shown). In fact, the lack of correlation between culturability and respiration has been reported earlier, and it has even been indicated that tetrazolium salts could be reduced by quiescent redox systems, questioning their suitability for viability evaluation (7). On the other hand, Yamamoto (44) stated that respiratory activity is a more stringent indicator of viability than, for instance, membrane integrity. In general, respiratory activity may not be the only reliable parameter for evaluating bacterial activity, considering that it also depends sometimes on experimental conditions (45) or the response of the bacteria to the addition of nutrients (29). Besides, any significant changes in respiratory activity could not be detected by measuring percentage INT-positive cells if such changes were occurring in very small portions of the total cell populations.

A typical pattern of cell growth was observed when nonstressed cells were incubated in distilled water despite the total absence of nutrients: the final CFU number was higher than the theoretical initial total cell number, which should not have been surpassed, had only "resuscitation" taken place (Fig. 4A). Culturable cell numbers in $\mathrm{Cu}$ solutions did not exceed the theoretical total cell number present initially in the culture (Fig. $4 \mathrm{~B})$ but the doubling time of non-treated cells was not substantially different from the doubling time calculated for $\mathrm{Cu}$-treated cells. In the past, this approach was used to prove the presence of non-culturable cells in $V$. vulnificus and $E$. amylovora $(34,43)$ and this phenomenon has also been reported for $R$. solanacearum $(14,40)$. It seems apparent that those increasing culturable populations exceeding the initial total cell number are actually multiplying (Fig4A), and rational to assume that those reaching but not eventually surpassing the initial cell density (Fig. 4B) represent the populations that are only recovering culturability, since the increase in culturable cells does not accompany an increase in metabolic activity (i.e. respiration). However, nalidixic acid clearly interrupted the increase of culturable cells after the onset of $\mathrm{Cu}$ stress (Fig. 6A). Previous studies using this antibiotic to demonstrate the viability of bacterial cells $(20,29)$ reported the strong dependence of this antibiotic on nutrient enrichment in order to affect bacterial cells. Additionally, it is known that this antibiotic acts on actively multiplying cells by affecting their DNA replication machinery. In this study, nalidixic acid did not affect culturability of cells when added $0 \mathrm{~h}$ or $36 \mathrm{~h}$ after the addition of copper, indicating that such cells were not in the mode of multiplication. Thus, the results demonstrate that the apparent increase in culturable cells was a result of multiplication and such cells have enough nutrient reserves to multiply. Nonetheless, in order to have a more conclusive evidence of multiplication, it might be necessary to quantify the number of DNA copies during this "recovery". This may be possible by real time PCR, in which any increase of DNA due to cell multiplication may be quantified by selecting a proper sequence. The fact that cells did not suffer the $\mathrm{Cu}$ effect when nalidixic acid was added at the same time as $\mathrm{Cu}(0 \mathrm{~h})$ can be explained by the ability of nalidixic acid, a quinolone, to chelate $\mathrm{Cu}$ and other metals to form complexes, as has been studied extensively (39).

If we accept the possibility of cell multiplication in oligotrophic environments as suggested by the test with nalidixic acid, one likely explanation to this is that such cells undergo cell division in the absence of nutrients by reducing their size. It has been well documented that bacterial cells in the nutrient-depleted environments are smaller than those found in the nutrient-rich environments (10) and they become dwarf cells under stressful conditions (24). The dwarf cells are less than $0.3 \mu \mathrm{m}$ in size, and such extremely small cells are found abundantly in soil (5). However, these extremely small 
cells could not be observed either in this study due to the limitation in the methodology employed (i.e. light microscope) or in previous studies (42). Another possibility is that the cells multiplied in distilled water by utilizing what was left in their cellular reserve or extracellular polysaccharide capsule. Nevertheless, an intriguing phenomenon observed was that the populations of culturable cells typically plateaued at approx. $7.0 \log \mathrm{CFU} \mathrm{m} \mathrm{m}^{-1}$ in all cases (Figs. 1A, 2, 4B, 5A, 8B). No explanation to this is available at this point. It seems that this definite number may have some significant biological relevance or may be determined simply by the size of tubes used in the in vitro tests. In all, the biological functions of culturability and the number and size of the cells in a given bacterial population need to be studied in great detail to fully understand the behavior of $R$. solanacearum.

Another significant finding in this study is the distinctive differences in the responses of $\mathrm{Cu}$-stressed cells when inoculated to the soil versus water (Fig. 7 and Fig. 8). Nonculturable cells induced by $20 \mu \mathrm{M} \quad \mathrm{CuSO}_{4}$ regained culturability in the water microcosms as observed in the previous tests, but the same was not observed in soil. Furthermore, the increase in culturability was pronounced at both high and low $\mathrm{Cu}$ concentrations when the inocula were enriched with nutrients. These results suggest that the availability of nutrients is the limiting factor for the $\mathrm{Cu}$ stressed cells to recover in soil. It is likely that the increased availability of nutrients enabled the cells to produce more peptides with sulfhydryl group, to which $\mathrm{Cu}$ binds to reduce its toxicity (38). It was also demonstrated that various nutrients bind $\mathrm{Cu}$ ions to diminish the deleterious effect of $\mathrm{Cu}(32,34)$. It is noteworthy that, although no culturable cells were detected in the solution containing $40 \mu \mathrm{M} \mathrm{CuSO}$, some residual culturable populations were detected when those nonculturable cells were inoculated to the soil. This may indicate that the soil actually contained a minute amount of nutrients to be used by the non-culturable 22R6 that otherwise remained non-culturable in the total absence of nutrients in distilled water.

The test in pasteurized soil showed that recovery of culturability was hindered by the presence and activity of other soil microorganisms competing for nutrients (Fig. 8). In fact, even without addition of nutrients, culturable cell numbers of strain 22R6 increased in pasteurized soil but not in nonpasteurized, natural soil. This indicates that deactivation and death of soil microorganisms by pasteurization increased nutrient availability in the soil, triggering non-culturable cells to regain their culturability and start to multiply as they were in distilled water. Soil fungi as well as soil bacteria seemed to prevent the non-culturable cells of 22R6 from regaining their culturability and multiplying, since soil fungi are in general more sensitive to heat than soil bacteria $(8,15)$ and soil pasteurization at both temperatures had similar effects on the non-culturable cells. This might be an exclusive phenomenon of $\mathrm{Cu}$-stressed cells of $R$. solanacearum, since soil amendment with organic substances has previously been reported to reduce the pathogen population of fresh, unstressed cells when inoculated into natural soil (6), probably due to the increase of antagonists already present in that soil. This may be an important discrimination to be made when studying this pathogen's ecology, since we have demonstrated that $\mathrm{Cu}$ stressed cells have at least some physiological differences with fresh unstressed cells.

In all, we have showed that survival of $\mathrm{Cu}$-stressed $R$. solanacearum in water is superior to that in bulk soil. This has implications on the epidemiology of the pathogen and directly affects control methods based on exclusion of inoculum. It is clear that, as long as nutrients are available, $R$. solanacearum can survive very well in soil even in the presence of $\mathrm{Cu}$. This suggests that the efficacy and reliability of culture-dependent detection can be improved by incubating soils with nutrients prior to the assay, since this would increase the threshold of detection when detection is based on the plus/minus basis. The soil enrichment should also increase the sensitivity of cultureindependent methods by increasing the minimum threshold 
population for detection in various types of soil. In water, on the other hand, the lack of nutrients does not necessarily limit survival and population growth of the pathogen. We feel that the epidemiology of this bacterium in water is affected not only by low temperature (12) but also by toxic metals and compounds, and the latter effects should receive more attention. This is of great importance, for instance, in tropical regions where $\mathrm{Cu}$ is frequently used to control various plant diseases while heavy rains may wash contaminated soils in and out of farming fields. Further studies on the survival of nonculturable $R$. solanacearum in water in conjunction with the effects of toxic metals and other environmental substances should provide valuable information to improve the efficacy and reliability of culture-dependent methods for detecting the pathogen.

\section{ACKNOWLEDGEMENTS}

This research was possible thanks to the financial support of The Japanese Government Scholarship (Monbukagakusho). We also thank the Japanese Ministry of Agriculture, Forestry and Fisheries (MAFF) for providing the strain used in this study. We are grateful to Steve E. Lindow for reviewing the manuscript and for his valuable suggestions.

\section{REFERENCES}

1. Agrios, G.N. (2005). Plant Pathology. Elsevier Academic Press, Burlington, MA.

2. Alvarez, A.M. (2005). Diversity and diagnosis of Ralstonia solanacearum. In: Allen, C.; Prior, P.; Hayward, A.C. (eds). Bacterial Wilt Disease and the Ralstonia solanacearum Species Complex. APS Press, St. Paul, MN, p. 437-447.

3. Alvarez, B.; Lopez, M.M.; Biosca, E.G. (2008). Survival strategies and pathogenicity of Ralstonia solanacearum phylotype II subjected to prolonged starvation in environmental water microcosms. Microbiology. 154, 3590-3598.

4. Arahal, D.R.; Llop, P.; Perez Alonso, M.; Lopez, M.M. (2004). In silico evaluation of molecular probes for detection and identification of Ralstonia solanacearum and Clavibacter michiganensis subsp. sepedonicus. System. Appl. Microbiol. 27, 581-591.
5. Bae, H.C.; Cota-Robles, E.H.; Casida Jr, L.E. (1972). Microflora of soil as viewed by Transmission Electron Microscopy. Appl. Environ. Microbiol. 23, 637-648.

6. Bagarinao Posas, M.; Toyota, K.; Islam, T.M.D. (2007). Inhibition of bacterial wilt of tomato caused by Ralstonia solanacearum by sugars and amino acids. Microbes Environ.. 22, 290-296.

7. Barer, M.R.; Gribbon, L.T.; Whiteley, A.S.; Smith, R.; Newton, A.; O'Donnell, A.G. (2000). Relationships between cellular activity and culturability. Microbial Biosystems: New Frontiers. Proceedings of the 8th International Symposium on Microbial Ecology. Halifax, Canada. .

8. Bollen, G.J. (1969). The selective effect of heat treatment on the microflora of a greenhouse soil. Neth. J. Pl. Path. 75, 157-163.

9. Boudazin, G.; Le Roux, A.C.; Josi, K.; Labarre, P.; Jouan, B. (1999). Design of division specific primers of Ralstonia solanacearum and application to the identification of European isolates. Eur. J. Plant Pathol. 105, 373-380.

10. Byrd, J.J. (2000). Morphological changes leading to the nonculturable state. In: Colwell, R.R.; Grimes, D.J. (eds). Nonculturable Microorganisms in the Environment. ASM Press, Washington D.C, p. 718.

11. Caruso, P.; Bertolini, E.; Cambra, M.; Lopez, M.M. (2003). A new and sensitive co-operational polymerase chain reaction for rapid detection of Ralstonia solanacearum in water. J. Microbiol. Method. 55, 257-272.

12. Caruso, P.; Palomo, J.; Bertolini, E.; Alvarez, B.; Lopez, M.; Biosca, E. (2005). Seasonal variation of Ralstonia solanacearum biovar 2 populations in a Spanish river: Recovery of stressed cells at low temperatures. Appl. Environ. Microbiol. 71, 140-148.

13. Cooksey, D.A. (1993). Copper uptake and resistance in bacteria. Mol. Microbiol. 7, 1-5.

14. Coutinho, T.A. (2005). Introduction and prospectus on the survival of Ralstonia solanacearum. In: Allen, C.; Prior, P.; Hayward, A.C. (eds). Bacterial Wilt Disease and the Ralstonia solanacearum Species Complex. APS Press, St. Paul, MN, p. 29-38.

15. Davet, P. (2004). Microbial Ecology of the Soil and Plant Growth. Science Publishers, Enfield, NH.

16. Dittapongpitch, V.; Surat, S. (2003). Detection of Ralstonia solanacearum in soil and weeds from commercial tomato fields using immunocapture and the polymerase chain reaction. J. Phytopathol. 151, 239-246.

17. Elphinstone, J.G. (2005). The current bacterial wilt situation: A global overview. In: Allen, C.; Prior, P.; Hayward, A.C. (eds). Bacterial Wilt Disease and the Ralstonia solanacearum Species Complex. American Phytopathological Society Press, St. Paul, MN, p. 9-28.

18. French, E.B.; Gutarra, L.; Aley, P.; Elphinstone, J. (1995). Culture media for Ralstonia solanacearum isolation, identification and maintenance. Fitopatologia. 30, 126-130.

19. Fukui, R.; Schroth, M.N.; Hendson, M.; Hancock, J.G.; Firestone, M.K. 
(1994). Growth patterns and metabolic activity of pseudomonads in sugar beet spermospheres: Relationship to pericarp colonization by Pythium ultimum. Phytopathology. 84, 1331-1338.

20. Grey, B.E.; Steck, T.R. (2001). The viable but nonculturable state of Ralstonia solanacearum may be involved in long-term survival and plant infection. Appl. Environ. Microbiol. 67, 3866-3872.

21. Harrison, J.J.; Ceri, H.; Turner, R.J. (2007). Multimetal resistance and tolerance in microbial biofilms. Nat. Rev. Microbiol. 5, 928-938.

22. Horita, M.; Yano, K.; Tsuchiya, K. (2004). PCR-based specific detection of Ralstonia solanacearum race 4 strains. J. Gen. Plant. Pathol. 70, 278283.

23. Ito, S.; Ushijima, Y.; Fujii, T.; Tanaka, S.; Kameya-Iwaki, M.; Yoshiwara, S.; Kishi, F. (1998). Detection of viable cells of Ralstonia solanacearum in soil using a semiselective medium and a PCR technique. J. Phytopathology. 146, 379-384.

24. Kieft, T.L. (2000). Size matters: Dwarf cells in soil and subsurface terrestrial environments. In: Colwell, R.R.; Grimes, D.J. (eds). Nonculturable Microorganisms in the Environment. ASM Press, Washington D.C, p. 19-39.

25. Knight, I.T. (2000). Molecular genetic methods for detection and identification of viable but nonculturable microorganisms. In: Colwell, R.R.; Grimes, D.J. (eds). Nonculturable Microorganisms in the Environment. ASM Press, Washington D.C, p. 77-86.

26. Komatsu, T. (2001). Effect of earthworms on the production of sludge manure and on the availability of heavy metals in the applied soils. Utsunomiya, Japan (In Japanese). (Utsunomiya University).

27. Lee, Y.A.; Wang, C.C. (2000). The design of specific primers for the detection of Ralstonia solanacearum in soil samples by polymerase chain reaction. Bot. Bull. Acad. Sin. 41, 121-128.

28. Louws, F.J.; Rademaker, J.L.W.; De Bruijin, F.J. (1999). The three D's of PCR-based genomic analysis of phytobacteria: Diversity, detection, and disease diagnosis. Annu. Rev. Phytopathol. 37, 81-125.

29. McDougald, D.; Rice, S.A.; Weichart, D.; Kjelleberg, S. (1998). Nonculturability: adaptation or debilitation?. FEMS Microbiol. Ecol. 25, $1-9$.

30. Miller, W.G.; Brandl, M.T.; Quiñones, B.; Lindow, S.E. (2001). Biological sensor for sucrose availability: Relative sensitivities of various reporter genes. Appl. Environ. Microbiol. 67, 1308-1317.

31. Nies, D.H. (1999). Microbial heavy-metal resistance. Appl. Microbiol. Biotechnol. 51, 730-750.

32. Noyce, J.O.; Michels, H.; Keevil, C.W. (2006). Use of copper cast alloys to control Escherichia coli 0157 cross-contamination during food processing. Appl. Environ. Microbiol. 72, 4239-4244

33. OEPP/EPPO (2004). Diagnostic protocols for regulated pests. Ralstonia solanacearum. OEPP/EPPO Bull. 34, 173-178.

34. Ordax, M.; Marco-Noales, E.; López, M.M.; Biosca, E.G. (2006). Survival strategy of Erwinia amylovora against copper: induction of the viable-but-nonculturable state. Appl. Environ. Microbiol. 72, 3482-3488.

35. Pastrik, K.H.; Maiss, E. (2000). Detection of Ralstonia solanacearum in potato tubers by polymerase chain reaction. J. Phytopathology. 148, 619626.

36. Saile, E.; Mc Garvey, J.A.; Schell, M.A.; Denny, T. (1997). Role of extracellular polysaccharide and endoglucanase in root invasion and colonization of tomato plants by Ralstonia solanacearum. Phytopathology. 87, 1264-1271.

37. Schönfeld, J.; Heuer, H.; Van Elsas, J.D.; Smalla, K. (2003). Specific and sensitive detection of Ralstonia solanacearum in soil on the basis of PCR amplification of fliC fragments. Appl. Environ. Microbiol. 69, 7248-7256.

38. Tortora, G.J.; Funke, B.R.; Case, C.L. (2004). Microbiology: An Introduction. Benjaming Cummings, San Francisco, CA.

39. Turel, I. (2002). The interactions of metal ions with quinolone antibacterial agents. Coord. Chem. Rev. 232, 27-47.

40. Van Elsas, J.D.; Van Overbeek, L.S.; Trigalet, A. (2005). The viable but non-culturable state in Ralstonia solanacearum: Is there a realistic threat to our strategic concepts?. In: Allen, C.; Prior, P.; Hayward, A.C. (eds). Bacterial Wilt Disease and the Ralstonia solanacearum Species Complex. APS Press, St. Paul, MN, p. 103-119.

41. Van Overbeek, L.S.; Bergervoet, J.H.W.; Jacobs, F.H.H.; Van Elsas, J.D. (2004). The low-temperature-induced viable-but-nonculturable state affects the virulence of Ralstonia solanacearum biovar 2 . Phytopathology. 94, 463-469.

42. Wakimoto, S.; Utatsu, I.; Matsuo, N.; Hayashi, N. (1982). Multiplication of Pseudomonas solanacearum in pure water. Ann. Phytopath. Soc. Japan. 48, 620-627.

43. Whitesides, M.D.; Oliver, J.D. (1997). Resuscitation of Vibrio vulnificus from the viable but nonculturable state. Appl. Environ. Microbiol. 63, 1002-1005.

44. Yamamoto, H. (2000). Viable but nonculturable state as a general phenomenon of non-spore-forming bacteria, and its modeling. J. Infect. Chemother. 6, 112-114.

45. Yokomaku, D.; Yamaguchi, N.; Nasu, M. (2000). Improved direct viable count procedure for quantitative estimation of bacterial viability in freshwater environments. Appl. Environ. Microbiol. 66, 5544-5548. 